\title{
The Difficulties That the Teachers Who Continue Master of Science Education Experience
}

\author{
Murat Çalışoğlu ${ }^{1} \&$ Abdul Samet Yalvaç ${ }^{2}$ \\ ${ }^{1}$ Basic Education Department, Ağrı İbrahim Çeçen University, Ağrı, Turkey. \\ ${ }^{2}$ Graduate Student, Institute of Social Sciences, Ağrı İbrahim Çeçen University Ağrı, Turkey. \\ Correspondence: Murat Çalışoğlu, Basic Education Department, Ağrı İbrahim Çeçen University, 04100 Ağrı, \\ Turkey.
}

Received: November 12, 2018

doi:10.5539/ies.v12n4p100

\author{
Accepted: December 20, 2018 \\ Online Published: March 20, 2019 \\ URL: https://doi.org/10.5539/ies.v12n4p100
}

\begin{abstract}
Postgraduate education includes Master's, $\mathrm{PhD}$, specialty in medicine and proficiency in art after the undergraduate education. Postgraduate education is a high-level education program that provides a specialization in the field of science in which students are interested following a four-year undergraduate program in faculties. Teachers also continue their postgraduate education in order to improve themselves and to make a professional contribution. The purpose of this study is to determine the difficulties encountered by teachers who are continuing their graduate education. The research group consists of 29 teachers working in Ministry of National Education and continued master's with thesis education in 2017-2018 academic years, and they were selected with purposeful sampling. In the study, the qualitative research method was used. The data collection tool consisted of the personal information protocol and the interview form consisting of 5 open-ended questions developed by the researcher. In the presentation of the data, the frequency and percentage values of the personal information of the participants were tabulated. As a result of the study, it was determined that the participants had problems such as the distance between the university and the school, the training being a tiring process, the problem of attendance and the inadequacy of the incentives to complete the education and the inadequacy of the rights given in the case of the completion of the education.
\end{abstract}

Keywords: postgraduate education, master's degree with thesis, teacher opinions

\section{Introduction}

Education has the functions of transferring the social and cultural values of the current system to future generations, maintaining the lives of individuals and achieving satisfaction at the level of knowledge (Alhas, 2006). Gökçe (2000, p. 126) defined education as "a process in which young people are accustomed to old values, transformation of cultural heritage, professional training, a free art, mental development, personality development, equipping individuals with technological skills and maintaining the social-political system" (Gökçe, 2000; Alhas, 2006). Tezcan (1985) defines education as "a social process that involves a chosen and supervised environment (especially school) in order to achieve the social ability of the individual and the most favorable personal development." Education is defined as the process of creating a change in the individual's behavior, through his own life, and for purpose (Tezcan, 1985).

Universities, which are one of the educational institutions, carry out higher education. Higher education helps in the development of science, the advancement of technology and the solution of the problems of the country. Universities continue their education with various programs in line with their function to train qualified employee and competent person required by the society. One of the programs given in the continuation of the undergraduate program is the graduate programs (master and doctorate) (Ünal \& İlter, 2010). Postgraduate education is a training program that trains experts who have a higher level of knowledge and competence than undergraduate education by working in depth in a certain area. Although it has different functions, the aim is to educate scientists, experts, lecturers and researchers (Karaman \& Bakırc1, 2010).

In the past, while educating qualified people in universities was aimed with undergraduate programs, nowadays, there is a need for graduate programs to train more skilled and qualified people (Katılmış, Çelik, \& Yaşar, 2013). 
In this context, the aims of master's and doctoral programs are expressed by the Council of Higher Education [CHE], the most upperstructure and the roof of higher education in Turkey, as follows:

"ARTICLE 6 - (1) The master's program with thesis enables the student to gain the ability to access, compile, interpret and evaluate information by using scientific research methods."

ARTICLE 15 - (1) The doctoral program provides the student with the necessary skills to conduct independent research, to analyze scientific problems and data from a broad and deep perspective to reach new syntheses." (YÖK, 2016) Postgraduate education has important implications for the development of scientists and policies. The main objective is to train the manpower that produces the information, uses the knowledge he produces and can solve the problems he faces. Therefore, postgraduate education should be planned well and contribute to the level of development of countries (Alhas, 2006). Postgraduate education is a programmatic education level in terms of the development of scientists in the social, cultural and educational contexts and the use of technology at the highest level (Çoruk, Çağatay, \& Öztürk, 2015).

As a result of the developments in today's information societies, the teacher does not transfer the information to the student through the renewed educational programs, but he is the guide for the student to reach the information. For this reason, the role of the teacher in education and teaching levels is increasing day by day. Training of qualified teachers and self-development of teachers have gained importance. Because teachers are one of the most important factors in the basis of education and student success (Unal \& Ilter, 2010).

As it can be understood from the aims given, graduate education is very important not only to educate qualified and research people, but also to educate scientists. As a result of national literature review, it was determined that there are studies by Karakütük (2000), Başer, Narlı, and Günhan (2005), Sayan and Aksu (2005), Alhas (2006), Kuzu and Becit (2007), Alabaş, Kamer, and Polat (2012) and Katılmış, Çelik, and Kop (2013) which are about the graduate education especially related to teachers, and these studies will be mentioned comparatively in the results section of the study.

According to the international literature review, we haven't found any study directly examine the difficulties that the teachers who continue graduate education experience, but below studies related to graduate education was determined. In their study, Filippou, Kallo, and Erdmann (2017) examined the views of graduate students from different cultures in Finland, and Ward and Dixon (2014), in their study in which they used self-efficacy scale of Bandura, examined the graduate education status of experienced teachers. In the study by Osipian (2012), the corruption in the graduate education in the USA and Russia was analyzed comparatively. In addition, Sin (2012) dealt with Bologna related to the graduate education in European countries. Cohen (2012) conducted a study with 2240 students related to personality traits of the graduate students. In another study by Ladd and Sorensen conducted in the USA, they analyzed the developments of the teachers through graduate education and which branch teachers do graduate education more.

Teachers need graduate education to improve themselves academically and contribute to their professional knowledge. With the directive enforced in 2005, the teachers doing graduate education were given two half day off and enabled to take their graduate education. However, with a new directive in 2013, this article was changed and the initiative to prepare the schedule of the teachers who continue their graduate education to enable them to maintain their education was left to the school principals (05/04/2013-MEB). The teachers who are still in the course period in their graduate education are to maintain seventy percent (70\%) of attendance to the courses in the graduate education programs except for the distance education programs. In particular, the obligation to attend the courses and leaving this authorization to the school principals brings some difficulties experienced by the teachers during the graduate education process.

The purpose of this study is to determine the opinions of the teachers who are continuing their master's education regarding the difficulties they encounter. Answers to the following questions were sought for this purpose:

- What are the difficulties you are experiencing in terms of attendance and the factors that lead to these difficulties in graduate education?

- What are the positive and negative aspects of being a teacher and a student at the same time?

- What are your positive and negative opinions and suggestions regarding the legislation of the Ministry of National Education for teachers with postgraduate education?

- Please give information about the attitude of the institution you are working in about your attendance in the lessons of graduate education.

- Please give information about the attitudes and behaviors of the faculty members regarding attendance. 


\section{Method}

In this section, the model of the study, the study group, data collection and analysis of the data are given.

\subsection{Research Model}

The research was conducted as a qualitative study. Qualitative research is a method of realizing perceptions and events using realistic data collection methods such as observation, interview and document analysis (Yıldırım \& Şimşek, 2016). In this way, it is aimed to examine the problems experienced by the teachers who received graduate education in depth.

\subsection{Research Group}

The sample of the study consisted of 29 teachers, 15 males and 14 females, who were in the class period and continue their graduate education in the 2017-2018 academic year, and they were selected with criterion sampling method. In purposive sampling, the researchers use their personal judgment to select who will be selected to the research group and determine the participants according to the most appropriate characteristics for the study (Başkale, 2016). In the criterion sampling method, people, events and objects involved in the study are selected according to the criteria determined by the researcher or predetermined (Büyüköztürk, 2014; Yıldırım \& Şimşek, 2016).

\subsection{Data Collection Tools}

The interview protocol prepared by asking expert opinions was used in obtaining the data. The first section of the data collection tool which is two sections, includes personal information of the participants and the second section includes questions about the problems experienced by the participants in graduate education and the positive and negative aspects of the graduate education. For the validity of these questions which were developed by the researchers, the opinions of three faculty members, who have full knowledge of scientific research methods and who give lectures in graduate education, were consulted. After doing suggested corrections and additions, the necessary arrangements were done on the data collection tool and semi-structured interview protocol was given its final shape.

\subsection{Analysis of the Data}

Descriptive analysis is used in data analysis. The purpose of descriptive analysis is to summarize and interpret the data. Thus, direct quotations are frequently given to expose and reflect the views of the interviewed or observed individuals (Yıldırım \& Şimşek, 2016). Frequency and percentage distributions were used in the presentation of the data. The teachers who participated in the study were coded as $\mathrm{T}$ (Teacher) and numbered from 1 to 18 (T-1, $\mathrm{T}-2, \mathrm{~T}-3$, etc.). Direct quotations from the responses of the participants are included in the findings section of the study.

\section{Findings and Interpretation}

In this section, the frequency distributions of the findings obtained in the research were tabulated, presented and interpreted. 
Table 1. The distribution of the frequency and percentage values of the answers to the question "What are the difficulties you are experiencing in terms of attendance and the factors that lead to these difficulties in graduate education?"

\begin{tabular}{|c|c|c|}
\hline $\begin{array}{l}\text { The difficulties you are experiencing in terms of attendance and the factors that lead to these difficulties in } \\
\text { graduate education }\end{array}$ & $\begin{array}{l}\text { Frequency } \\
(\mathrm{N})\end{array}$ & $\begin{array}{l}\text { Percentage } \\
(\%)\end{array}$ \\
\hline The distance between the school and the university & 8 & 20 \\
\hline Conflicts between school and university lecture hours & 7 & 17.5 \\
\hline Transportation and road & 6 & 15 \\
\hline School management make problems in the adjustment of school courses according to my graduate courses & 5 & 12.5 \\
\hline Graduate courses are collected in one day & 3 & 7.5 \\
\hline Having difficulty in terms of time & 3 & 7.5 \\
\hline Permissions are left to the initiative of the principals & 2 & 5 \\
\hline Attendance to the lessons are costly & 1 & 2.5 \\
\hline Compulsory attendance & 1 & 2.5 \\
\hline Intensive research, study and assignments & 1 & 2.5 \\
\hline Having graduate education in different branches & 1 & 2.5 \\
\hline Family life and responsibilities of the children & 1 & 2.5 \\
\hline I have problems in reaching the sources & 1 & 2.5 \\
\hline Total & 40 & 100 \\
\hline
\end{tabular}

When the Table 1 is analyzed, it is seen that $20 \%$ of answers of the teachers are about the distance between the school and the university, $17.5 \%$ are about conflicts between school and university lecture hours, $15 \%$ are about transportation and road, $12.5 \%$ are about school management make problems in the adjustment of school courses according to my graduate courses, $7.5 \%$ are about graduate courses are collected in one day, $7.5 \%$ are about having difficulty in terms of time, $5 \%$ are about permissions are left to the initiative of the principals, $2.5 \%$ are about attendance to the lessons are costly, $2.5 \%$ are about compulsory attendance, $2.5 \%$ are about intensive research, study and assignments, $2.5 \%$ are about having graduate education in different branches, $2.5 \%$ are about family life and responsibilities of the children, $2.5 \%$ are about having problems in reaching the sources.

Some views of the teachers regarding the problems encountered are as follows:

T-18: “The city where I live is far from the city where I do master's degree:" T-23: "The biggest problem is the distance between where I live and the faculty. Setting off early in the morning for a long trip causes exhaustion during the day." T-22: "The distance between my home and university is far-off. I wake up at 5 for the morning classes." T-17: "Course hours do not fit in with the working hours of the organization I work for, most of the time, I cannot make it to the class hours." T-21: "As I work in a full-time school, I cannot attend to the lessons within the hour of work." T-25: "Road is the leading problem among the problems I experience. The fact that the distance between the place where I work and the place where I take graduate education is far-off causes problems." T-27: “... the courses are on different days; therefore, I have difficulty in getting permission from the organization I work for and arranging my hour of work accordingly. ”

T-5: "First of all, I have no support from my school about this situation. They are hardly arranging my schedule according to my graduate education. Let me give you an example, on some days, I leave the class in the university at 13:40 and I have to be at school at 14:15, I catch the class in school with taxi and breathless. This shouldn't be left to the initiatives of the principals." 
Table 2. The frequency and percentage values of the positive answers to the question "What are the positive and negative aspects of being a teacher and a student at the same time"

\begin{tabular}{lcc}
\hline The positive aspects of being a teacher and a student at the same time & Frequency (N) & Percentage (\%) \\
\hline I put the knowledge and experiences I get in the graduate education into practice in the school & 9 & 23.07 \\
I learn new things & 8 & 20.51 \\
I develop myself & 8 & 20.51 \\
I keep my information up-to-date by following the recent changes & 6 & 15.38 \\
I empathize & 3 & 7.70 \\
I pull myself away from the monotony of the school & 2 & 5.12 \\
I review my methods I use while teaching & 1 & 2.57 \\
I re-live the student life & 1 & 2.57 \\
I get to know different people & 1 & 2.57 \\
Total & 39 & 100 \\
\hline
\end{tabular}

When the Table 2 is analyzed, it is seen that $23.07 \%$ of the teachers participating in the study stated "I put the knowledge and experiences I get in the graduate education into practice in the school", $20.51 \%$ stated "I learn new things", $20.51 \%$ stated "I develop myself", $15.38 \%$ stated "I keep my information up-to-date by following the recent changes", 7.70\% stated "I empathize", 5.12\% stated "I pull myself away from the monotony of the school", $2.57 \%$ stated "I review my methods I use while teaching", $2.57 \%$ stated "I re-live the student life", and 2.57\% stated "I get to know different people."

The answers of the teachers to this question are as follows:

T-16: "It enables us to analyze theory and practice at the same time." T-25: "Getting graduate education while working as a teacher stimulates you to develop and refresh yourself. Your knowledge stays fresh and I can find the opportunity to implement the research or study I've done in my school." T-1: "I apply the knowledge and experience I gained in master's degree to teaching." T-20: "Being a teacher and continuing student life makes you active all the time and learn new things." T-7: "I can participate in many projects and research while doing master's, I can reflect it positively on my students thanks to the projects and field knowledge it brings." T-11: "That the teacher continues his professional and personal development and transfer this development to his students." T-19: "We can develop ourselves in our profession at the same time and we are much more informed about the recent changes and developments in the world."

Table 3. The frequency and percentage values of the negative answers to the question "What are the positive and negative aspects of being a teacher and a student at the same time"

\begin{tabular}{lcc}
\hline The negative aspects of being a teacher and a student at the same time & Frequency (N) & Percentage (\%) \\
\hline It is an exhausting and difficult process & 9 & 25.71 \\
I have time problem & 7 & 20 \\
My schedule conflicts with the demands of the faculty and the school & 5 & 14.29 \\
Too many responsibilities & 4 & 11.43 \\
I cannot do adequate preparation for the school and my students & 3 & 8.57 \\
I have difficulty in attendance & 2 & 5.71 \\
Being a student and doing homework & 2 & 5.71 \\
There is no cooperation between the institution and MoNE & 1 & 2.86 \\
Country trips are costly & 1 & 2.86 \\
I cannot devote myself to graduate education & 1 & 2.86 \\
Total & 35 & 100 \\
\hline
\end{tabular}

When the Table 3 is analyzed, it is seen that $25.71 \%$ of the teachers participating in the study think graduate education is "an exhausting and difficult process", $20 \%$ think "I have time problem", $14.29 \%$ think "My schedule conflicts with the demands of the faculty and the school", 11.43\% think it brings "Too many responsibilities", $8.57 \%$ state "I cannot do adequate preparation for the school and my students", $5.71 \%$ state "I have difficulty in attendance", $5.71 \%$ think "Being a student and doing homework", $2.86 \%$ think "There is no cooperation between the institution and MoNE", $2.86 \%$ think "Country trips are costly", and 2.86\% state "I cannot devote myself to graduate education." 
The answers of the teachers to this question are as follows:

T-7: "I get tired mentally and do a lot of homework, so I cannot spare time for myself, in addition, the cost of plane tickets, etc. put me in a hard condition economically as I travel too much." T-29: "Being a teacher and a student at the same time brings difficulties along with it. While fulfilling the responsibilities about being a student and assignments, I have hitches in fulfilling the responsibilities about being a teacher." T-4: "I cannot find enough time to do the assignments about the master's education, but I do them in the recess in the school." T-11: "I can say that the fact that I take of my students only during the class hours and being unable to create time periods to take care of them extracurricular are the negative aspects." T-21: "Trying to meet the demands of the both parties, even these demands conflict with each other, burns you out and drags you to negativity." T-1: "Both the responsibilities of being a teacher and the assignments from the graduate education to hand in time and the examinations we are supposed to prepare sometimes wears you down."

Table 4. The frequency and percentage values of the negative answers to the question "What are your positive opinions and suggestions regarding the legislation of the Ministry of National Education for teachers with postgraduate education?"

\begin{tabular}{lcc}
\hline $\begin{array}{l}\text { Your positive opinions and suggestions regarding the legislation of the Ministry of National Education for } \\
\text { teachers with postgraduate education?" }\end{array}$ & $\begin{array}{c}\text { Frequency } \\
(\mathrm{N})\end{array}$ & $\begin{array}{c}\text { Percentage } \\
(\%)\end{array}$ \\
\hline My school schedule is prepared according to my schedule in graduate education & 4 & 40 \\
I have no idea & 3 & 30 \\
The privileges provided to the teachers with graduate education are satisfactory. & 2 & 20 \\
When I participate in conferences and presentations, I receive the material and spiritual reward. & 1 & 10 \\
Total & 10 & 100 \\
\hline
\end{tabular}

As it can be seen in Table 4 when analyzed that $40 \%$ of the teachers participating in the study stated their school schedule is prepared according to their schedule in graduate education", $30 \%$ stated they have no idea, $20 \%$ stated they are satisfied with the privileges provided to the teachers with graduate education, and $10 \%$ stated when they participate in conferences and presentations, they receive the material and spiritual reward.

The answers to this question are as follows:

T-24: "When I tell that I'm doing master's degree, my schedule in the school is prepared accordingly. As there is a legislation about that, they don't raise any difficulties." T-4: "I have a day-off - whichever I want- according to my master's degree schedule." T-1: "The privileges on the teachers with graduate education both in terms of material and status are satisfactory."

Table 5. The frequency and percentage values of the negative answers to the question "What are your negative opinions and suggestions regarding the legislation of the Ministry of National Education for teachers with postgraduate education?"

\begin{tabular}{|c|c|c|}
\hline $\begin{array}{l}\text { Your negative opinions and suggestions regarding the legislation of the Ministry of National Education for } \\
\text { teachers with postgraduate education?" }\end{array}$ & $\begin{array}{l}\text { Frequency } \\
(\mathrm{N})\end{array}$ & $\begin{array}{c}\text { Percentage } \\
(\%)\end{array}$ \\
\hline Material and spiritual incentives supporting graduate education are not enough & 9 & 34.61 \\
\hline Permissions should not be in the administrative initiative & 5 & 19.23 \\
\hline Permissions are not specified in legislation & 3 & 11.54 \\
\hline Legislation does not help me & 3 & 11.54 \\
\hline I have no idea & 3 & 11.54 \\
\hline There should be an arrangement covering branch teachers & 2 & 7.69 \\
\hline The legislation is left open-ended & 1 & 3.85 \\
\hline Total & 26 & 100 \\
\hline
\end{tabular}

When the Table 5 is analyzed, it is seen that $34.61 \%$ of the teachers participating in the study stated material and spiritual incentives supporting graduate education are not enough, $19.23 \%$ stated permissions should not be in the administrative initiative, $11.54 \%$ stated permissions are not specified in legislation, $11.54 \%$ stated legislation does not help me, $11.54 \%$ stated they had no idea, $7.69 \%$ stated there should be an arrangement covering branch teachers, and $3.85 \%$ stated the legislation is left open-ended. 
The answers to this question are as follows:

T-7: "I am currently a graduate student, I got higher scores both from ALES and YDS, I'm planning to continue my PhD education, but unfortunately there is no material and spiritual encouragement to support my projects and academic success in our country." T-23: "A rank and 5\% raise in the additional course fee is not enough. There should be more financial possibilities." T-12: "We are also sorry about this. The ministry wants the teachers to develop themselves but there is no substantial thing in terms of wage and progress." T-21: "The fact that it is left to the initiatives of the principles creates a dilemma. Some of the administrators support you in this but some of them don't. The teachers who are not supported by the administration suffer from it." T-5: "That my school schedule corresponds to the schedule in the university shouldn't be left to the initiative of the principle."

Table 6. The frequency and percentage values of the negative answers to the question "Please give information about the attitude of the institution you are working in about your attendance in the lessons of graduate education."

\begin{tabular}{lcc}
\hline $\begin{array}{l}\text { The attitude of the institution you are working in about your attendance in the lessons of graduate } \\
\text { education }\end{array}$ & Frequency (N) & Percentage (\%) \\
\hline They don't make trouble, they are helpful & 18 & 64.28 \\
Graduate education is seen unnecessary, they don't give the due value & 4 & 14.29 \\
The school principal is not helpful, he tries to hinder & 4 & 14.29 \\
I'm exposed to criticism & 1 & 3.57 \\
My school gives me permission, but they demand something in return. & 1 & 3.57 \\
Total & 28 & 100 \\
\hline
\end{tabular}

When Table 6 is analyzed, it is seen that the $68.28 \%$ of the teachers stated their school does not make trouble but help, $14.29 \%$ stated graduate education is seen unnecessary by their school and they don't give due importance, $14.29 \%$ stated their school principal is not helpful and he tries to hinder, $3.57 \%$ stated they are exposed to criticism, and $3.57 \%$ stated their school gives permission but demand things in return.

The answers of the teachers to this question are as follows:

T-23: "My school planned my schedule appropriately according to my schedule in master's degree. My school principal and teacher colleagues support me in all ways." T-25: "My colleagues help me in terms of my attendance to the graduate classes and they support my graduate education." T-1: "My school does not make any troubles about my attendance to the graduate classes. They help me on this." T-4: "Generally, the school principle and some of the teachers think that doing master's degree is unnecessary and they don't give the due value." T-7: "My school principle caused a lot trouble. He tried to prevent my academic studies."

Table 7. The frequency and percentage values of the negative answers to the question "Please give information about the attitudes and behaviors of the faculty members regarding attendance."

\begin{tabular}{lcc}
\hline The attitudes and behaviors of the faculty members regarding attendance & Frequency $(\mathrm{N})$ & Percentage (\%) \\
\hline My university teachers are sensitive, they don't show tolerance & 7 & 23.34 \\
They are as much understanding as they can be & 7 & 23.34 \\
I have both understanding and inconsiderate teachers & 5 & 16.66 \\
My teachers are always understanding & 4 & 13.33 \\
They show tolerance towards indispensable cases & 4 & 13.33 \\
They make trouble if we have less attendance than we are supposed to & 3 & 10 \\
Total & 30 & 100 \\
\hline
\end{tabular}

When Table 7 is analyzed, it is seen that $23.34 \%$ of the participants stated their teachers are sensitive and show no tolerance, $23.34 \%$ stated they are as much understanding as they can be, $16.66 \%$ stated they have both understanding and inconsiderate teachers, $13.33 \%$ stated their teachers are always understanding, $13.33 \%$ stated they show tolerance towards indispensable cases, and $10 \%$ stated their teachers make trouble if they have less attendance than we are supposed to

The answers of the participants to this question are follows:

T-9: "My teachers display oppressive behaviors in terms of compulsory attendance." T-24: "They have a harsh feel about attendance." T-29: "Some of the teachers are insistent on the fact that attendance is compulsory. As a 
result, I face with some problems like failing due to absence." T-1: "All of my teachers are sensitive about attendance. They don't tolerate absence apart from indispensable cases." T-25: "I cannot put all my teachers in the same equation in terms of attendance. When exceed the absence limit and cannot attend to the classes because of personal conditions, most of my teachers show me the necessary flexibility." T-10: "Not to put the student in a hard condition but in a controlled manner." T-5: "There are tolerant and intolerant teachers in my university about this. I try to choose my courses accordingly." T-21: "Making a generalization should be wrong. Some of our teachers consider our excuses and try to enhance this as much as they can. Some of them expect others to adapt their ways."

\section{Results, Discussion and Recommendations}

This study was conducted to determine the problems the teachers who do master's degree in Turkey encounter. It was determined that the subject sample encounter significant problems in terms of administrative and academic dimensions.

In this sense, the major problem that the participants experience in terms of attendance to the graduate courses is the distance between the school and the university. The biggest crux of this problem is due to the fact that the city where they work and they city where they take undergraduate education are different cities. It is also seen that the conflict between their schedule in the school and their schedule in the graduate education causes problems in terms of attendance.

It is seen that being a teacher and a student at the same time is advantageous that they can apply the information and the experience acquired during graduate education in the school. In this frame, the teachers renew their knowledge constantly and make progress. The downside of being a teacher and student at the same time is that it is a difficult and exhausting process and they have time problem. It was stated that the Ministry's legislation on graduate teachers was not sufficient in terms of material and moral incentives. In addition, the fact that the permission rights of the teachers are in the administrative initiative cause the teachers to have problems in attendance to the classes. It is stated that the lecturers who teach in the institute are generally sensitive about attendance and do not show any tolerance.

When the literature is examined, in the study titled "The problems of teachers in graduate education and proposed solutions" by Başer, Narlı, and Günhan (2005), it was stated that teachers who get graduate education try to convey their knowledge to their students despite the difficulties they face, and this result is parallel to our study.

In the study titled "A qualitative study on the problems of non-academic staff who get graduate education: Dokuz Eylül University-Balıkesir University case study" by Sayan and Aksu (2005), It was determined that individuals who had to work and do graduate education at the same time had problems about permission. In the mentioned study, the results are similar to our study that wearing more than one hat, economic problems, being unable to spare enough time cause decrease in efficiency and energy. In a study titled as "The viewpoints of teachers working in MoNE with graduate education about the graduate education (Ankara sample)" conducted by Alhas (2006), it was determined that graduate education does not provide a financial gain to the individual, which is similar to the results of our study. Among the results of the study "The views of the administrators and teachers on the teacher's postgraduate education" by Karakütük (2000) that teachers who are graduate students do not have permission and support from MEB, Provincial Directorate of National Education or the institution they work for is similar to the results of our study. In the study "Problems in Master's Degree Programs in Turkey: Social Studies Education Case" by Katılmış, Çelik, and Kop (2013), it was determined that the participants have difficulty in getting permissions, which is similar to the results of our study.

In the study titled as "Postgraduate Education in Career Development of Teachers: Reasons of preference and the problems they encounter in the process" conducted by Alabaş, Kamer, and Polat (2012), the problem raised by the participants is the difficulties they experience in continuing their graduate courses. The reason for this is that universities do not take into consideration the students in planning the course hours and the managers in the schools where they work do not take initiative when planning the weekly course schedule of the teachers. These results are also similar to the results of our study. In the study "Problems and of Teachers in Graduate Education and Proposed Solutions" by Kuzu and Becit (2007), it was determined that there are problems in terms of attendance to the courses, and these problems are stated to be caused by the school the teachers work in and the university they get education. This showed parallelism to the results of our study.

Based on the results of this study, we can make the following recommendations to minimize the problems faced by the teachers who receive graduate education in their education process. 


\section{Recommendations}

- The permission of the teachers should not be on the initiative of the administrators and the permission period mentioned in the regulation should be reinstated as two half days or one full day.

- The Ministry of National Education should establish a clear, understandable and applicable policy for teachers who are doing postgraduate studies.

- Material and moral incentives should be improved to encourage teachers to graduate education.

- In order to be able to take the courses both face to face and with distance education, institutes should perform the necessary studies and prepare the infrastructure. Distance education courses will be healthier in terms of reducing the exhausting process and time loss of teachers.

- National education directorates and school administrators should be informed about the importance and necessity of graduate education.

- In order to minimize the negativities experienced by the teachers who are continuing their graduate education, they should be given the right to move to cities where the faculties and institutes they are educated are.

\section{References}

Alabaş, R., Kamer, S. T., \& Polat, Ü. (2012). Öğretmenlerin Kariyer Gelişimlerinde Lisansüstü Eğitim: Tercih Sebepleri ve Süreçte Karşılaştıkları Sorunlar. E-International Journal of Educational Research, 3(4).

Alhas, A. (2006). Lisansüstü eğitim yapmakta olan milli eğitim bakanlı̆̆l öğretmenlerinin lisansüstü eğitime bakış açıları (Ankara ili örneği). Yayınlanmamış yüksek lisans tezi, Ankara: Gazi Üniversitesi Eğitim Bilimleri Enstitüsü.

Osipian, A. L. (2012). Will bribery and fraud converge? Comparative corruption in higher education in Russia and the USA, Compare. A Journal of Comparative and International Education, 44(2), 252-273. https://doi.org/10.1080/03057925.2012.728374

Aytaçl, B. (2012). Durum çalışmasına ayrıntılı bir bakış. Adnan Menderes Üniversitesi Eğitim Fakültesi Eğitim Bilimleri Dergisi, 3(1).

Başer, N., Narlı, S., \& Günhan, B. (2005). Öğretmenlerin Lisansüstü Eğitim Almalarında Yaşanan Sorunlar ve Çözüm Önerileri. Dokuz Eylül Üniversitesi Buca Eğitim Fakültesi Dergisi, 17.

Başkale, H. (2016). Nitel araştırmalarda geçerlik, güvenirlik ve örneklem büyüklüğünün belirlenmesi. Dokuz Eylül Üniversitesi Hemşirelik Fakültesi Elektronik Dergisi, 9(1).

Büyüköztürk, Ş. (2016). Bilimsel Araştırma Yöntemleri (20. Baskı). Ankara: Pegem Akademi.

Cohen, K. E. (2012). What about Master's Students? The Master's Student Persistence Model. Association for the Study of Higher Education, Las Vegas, NV, November 15-17, 2012.

Sin, C. (2012). The Bologna master degree in search of an identity. European Journal of Higher Education, 2(2-3), 174-186. https://doi.org/10.1080/21568235.2012.702437

Çoruk, A., Çağatay, Ş. M., \& Öztürk, H. (2015). Lisansüstü Eğitimde Kayıt ve Devam Sorunları. Uşak Üniversitesi Sosyal Bilimler Dergisi, 25. https://doi.org/10.12780/uusbd.73894

Filippou, K., Kallo, J., \& Mikkilä-Erdmann, M. (2017). Students' views on thesis supervision in international master's degree programmes in Finnish universities. Intercultural Education, 28(3), 334-352. https://doi.org/10.1080/14675986.2017.1333713

Gökçe, F. (2000). Değişme Sürecinde Devlet ve Eğitim. Ankara: Eylül.

Kaldi, S., Govaris, C., \& Filippatou, D. (2018). Teachers' views about pupil diversity in the primary school classroom. A Journal of Comparative and International Education, 48(1), 2-20. https://doi.org/10.1080/03057925.2017.1281101

Karakütük, K. (2000). Öğretmenlerin lisansüstü öğretimi konusunda yönetici ve öğretmenlerin görüşleri. Dokuz Eylül Üniversitesi Buca Eğitim Fakültesi Dergisi, 12.

Karaman, S., \& Bakırcı, F. (2010). Türkiye'de lisansüstü eğitim: sorunlar ve çözüm önerileri. Sosyal Bilimler Araştırmaları Dergisi, II.

Katılmış, A., Çelik, H., \& KOP, Y. (2013). Türkiye'de yüksek lisans öğreniminde yaşanan sorunlar: Sosyal bilgiler öğretmenliği örneği. Gaziantep University Journal of Social Sciences, 12(1). 
Kuzu, A.; Becit, G. (2007). Öğretmenlerin Lisansüstü Eğitimde Karşılaştıkları Sorunlar ve Çözüm Önerileri. 17-20 Ekim 2007 Eskişehir. III. Lisansüstü Eğitim Sempozyumunda sunulmuş bildiri.

Ladd, H. F., \& Sorensen, L. C. (2015). Do Master's Degrees Matter? Advanced Degrees, Career Paths, and the Effectiveness of Teachers. CALDER Working Paper No. 136.

MEB. (2013). İzin Yönetmeliği. http://mevzuat.meb.gov.tr/dosyalar/1627.pdf

Riesa, F., Cabrerab, C. Y., \& Carriedoc R. G. (2016). A Study of Teacher Training in the United States and Europe. The European Journal of Social and Behavioural Sciences, 16, 2029-2054. https://doi.org/10.15405/ejsbs.184

Sayan, Y., \& Aksu, H. H. (2005). Akademik Personel Olmayan Lisansüstü Eğitim Yapan Bireylerin Karşılaştıkları Sorunlar Üzerine Bir Çalışma: Dokuz Eylül Üniversitesi, Balıkesir Üniversitesi Durum Belirlemesi. Dokuz Eylül Üniversitesi Buca Eğitim Fakültesi, 1.

Tezcan, M. (1985). Eğitim Sosyolojisi. Ankara: Ankara Üniversitesi Basımevi.

Unal, Ç., \& İlter, İ. (2010). Sınıf öğretmeni adaylarının lisansüstü eğitime olan tutumları (Fırat, Erzincan ve İnönü Üniversitesi sınıf öğretmenliği ABD örneği). Atatürk Üniversitesi Sosyal Bilimler Enstitüsü Dergisi, 14(2).

Ward, G., \& Dixon, H. (2014). The research masters experience: The impact of efficacy and outcome expectations on enrolment and completion. Journal of Further and Higher Education, 38(2), 163-181. https://doi.org/10.1080/0309877X.2012.706804

Yıldırım, A., \& Şimşek, H. (2016). Sosyal Bilimlerde Nitel Araştırma Yöntemleri. Ankara: Seçkin Yayınevi.

YÖK. (2016). Lisansüstü Ĕ̆itim ve Öğretim Yönetmeliği (Resmi Gazete, 20.04.2016, Say1: 29690). Retrieved from http://www.resmigazete.gov.tr/eskiler/2016/04/20160420-16.htm

\section{Note}

Note 1. This study was presented as a verbal notice in $27^{\text {th }}$ International Conference on Educational Sciences held in Antalya on 18-22 April 2018.

\section{Copyrights}

Copyright for this article is retained by the author(s), with first publication rights granted to the journal.

This is an open-access article distributed under the terms and conditions of the Creative Commons Attribution license (http://creativecommons.org/licenses/by/4.0/). 